\title{
Hawksbill turtles as significant predators on hard coral
}

Received: 11 January 2010/ Accepted: 8 March 2010/Published online: 25 March 2010

(C) Springer-Verlag 2010

Hawksbill turtles (Eretmochelys imbricata), originally thought to be almost exclusively spongivorous (Meylan 1988), were later found to have a more diverse diet, feeding in the wild on sessile invertebrates such as sponges, zooanthids, soft corals, corallimorphs, ascidians and mobile invertebrates (Leon and Bjorndal 2002). We report here hawksbill predation on live tissue of a hard coral, the bubble coral Physogyra lichtensteinii (Milne Edwards and Haime 1851). This coral has a soft blistery coenosteum with large exsert septa, it is fleshy with vesicles expanded during the day, and it secretes a large amount of mucus, prefers deeper reef slopes and is usually at low densities though can be locally abundant.

On the north shore of Aldabra atoll, $P$. lichtensteinii is the dominant coral between 20 and $35 \mathrm{~m}$ depth, at over 50\% cover (Fig. 1a). In March 2008, noting a high frequency of fresh and old lesions on P. lichtensteinii (Fig. 1b, c), we observed an adult hawksbill, sex undetermined, feeding on P. lichtensteinii tissue (Fig. 1d, e). Feeding appeared targeted at the coral tissue rather than at boring infauna or epifauna, and healthy $P$. lichtensteinii tissue is normally continuous without either of these. We have observed and received reports of similar behaviour on the Amirantes islands (Seychelles), Phi Phi islands (Thailand), Isle St. Marie (Madagascar) and the Sudanese Red Sea, and a hawksbill gut from Cosmoledo atoll contained Physogyra or Plerogyra (another bubble coral) tissue (J. A. Mortimer, personal communication). At Isle St. Marie, predation was also observed on Plerogyra. This behaviour appears to be widespread in the Indian Ocean, and similar though less extensive reports have been made for the Pacific and Caribbean.

On Aldabra, lesions on $P$. lichtensteinii were visually estimated to affect up to $5 \%$ of the species' cover and apart from the turtle predation, no other causative factors (such as disease or other predators) were observed. Feeding on bubble corals may relate to nutrition from their fleshy tissue, low bite-resistance from their soft skeletons and/or their copious mucus production. It is unknown how general this phenomenon is, and it is interesting to speculate on its possible ecological role in pre-modern times when turtles were more abundant than today (Jackson 1997).

References

Jackson JBC (1997) Reefs since Columbus. Coral Reefs 16:S23-S32

Leon YM, Bjorndal KA (2002) Selective foraging in the hawksbill turtle, an important predator in coral reefs ecosystems. Mar Ecol Prog Ser 245:249 258

Meylan A (1988) Spongivory in hawksbill turtles: a diet of glass. Science 239:393-395

D. O. Obura $(\bowtie)$

CORDIO East Africa, P.O. BOX 10135, 80101 Mombasa, Kenya

e-mail: dobura@cordioea.org

A. Harvey

The Nature Conservancy, Jl. Pengembak No. 2, Sanur, Bali 80228, Indonesia

T. Young

International Coral Reef Action Network (ICRAN), c/o UNEP WCMC, 219 Huntingdon Road, Cambridge CB3 0DL, UK

M. M. Eltayeb

IUCN Global Marine Program, P.O. Box 942230, Amman 11194, Jordan

R. von Brandis

D'Arros Research Centre (DRC), D'Arros Island, Amirantes, Seychelles

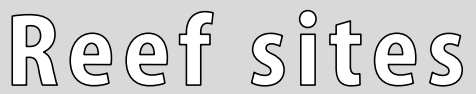

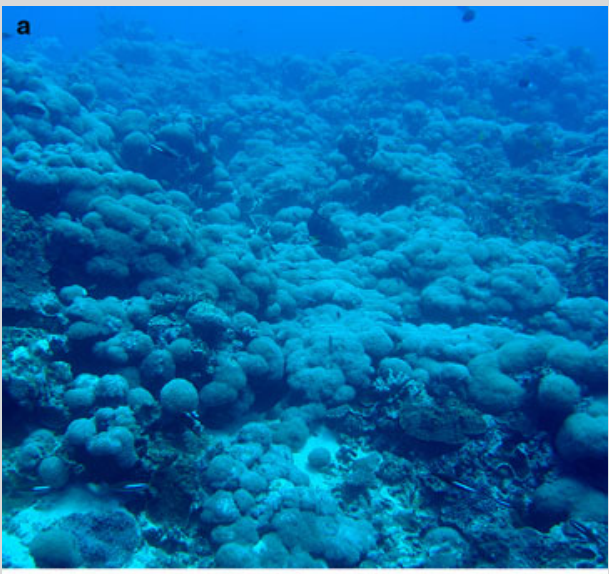
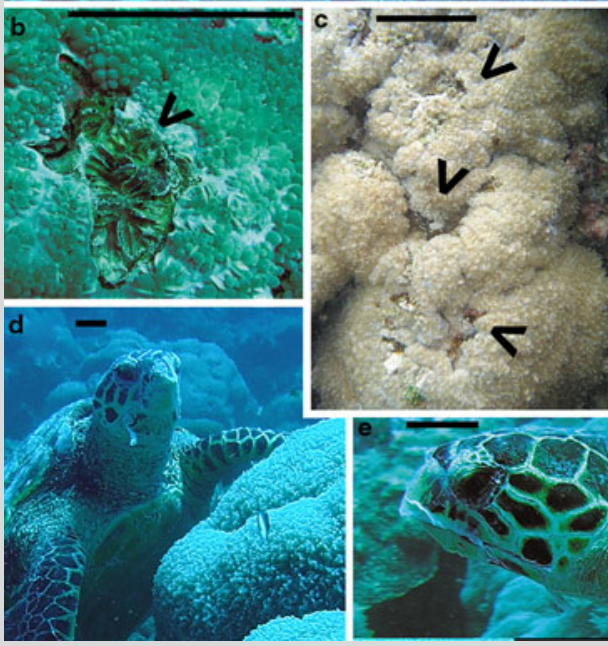

Fig. 1 a Physogyra lichtensteinii-dominated habitat on the north shore of Aldabra, at $25 \mathrm{~m}$ depth. b, $\mathbf{c}$ Lesions on the coral surface (indicated by arrows). d, e Hawksbill turtle after feeding, showing coral tissue trailing from the beak. Horizontal scale bars in b-e represent approximately $5 \mathrm{~cm}$

Coral Reefs (2010) 29:759 DOI $10.1007 / \mathrm{s} 00338-010-0611-8$ 